\title{
Resistance of rats to experimental infection with Neisseria gonorrhoeae despite attempts to alter cellular and humoral defences
}

\author{
J. FLYNN \\ Department of Medical Microbiology, The University, Sheffield
}

Although there have been many attempts, no one has yet succeeded in producing a gonococcal infection in a small, laboratory animal (Hill, 1943). The natural resistance of rats to a large number of human pathogens is known but not fully understood. Pillemer (1956) suggests that this resistance was due to the activity of properdin. Bertók, Kemenes, and Simon (1964) and Bertók and Szemerédi (1967) reported that the rat, which normally does not develop any clinical disease after exposure to infection with either Leptospira icterohaemorrhagiae or Listeria monocytogenes would, after having been maintained on a special diet containing DL-ethionine, develop a fatal infection with these organisms. He suggested that the reason for this was that DL-ethionine, an analogue of methionine, induces a methionine deficiency which leads to a lowering of complement and other natural antibodies.

As part of an investigation into possible ways of inducing susceptibility to gonococci in small laboratory animals, the use of this diet in rats was investigated.

\section{Material and methods}

White albino rats, weighing about 220 g., were caged in five groups of six, two groups being placed on normal diet and the other three being given the special diet (containing 0.4 per cent. DL-ethionine) used by Bertok. Food and water were given ad lib. The weight of the animals was checked each week and the daily food consumption measured twice weekly over the period of the experiment. Complement levels were checked by a modification of the method of Price (1949) before starting the experiment and again after 4 weeks of the diet.

\section{BACTERIA}

A freshly isolated strain of Neisseria gonorrhoeae was grown on 5 per cent. lysed blood agar for $14 \mathrm{hrs}$. The growth was scraped off and washed three times in Dulbecco's phosphate buffered saline pH 7.3. The

Received for publication November 17, 1971 bacteria were re-suspended in Dulbecco solution and bacterial counts were estimated by optical density readings on an EEL Nephelometer. By reference to previously prepared graphs, the turbidity of the suspension was adjusted so as to give an estimated count of $10^{9}$ organisms $/ \mathrm{ml}$. These figures were confirmed by Miles and Misra (1938) counts on chocolate blood agar.

At the end of the 4-week period the five groups of rats were used as follows:

One normal diet group was retained as a control and the other was inoculated intraperitoneally with $10^{9}$ gonococci.

Similarly, one special diet group was inoculated with $10^{9}$ gonococci, and one with $10^{9}$ gonococci killed by heating to $80^{\circ} \mathrm{C}$. for 10 minutes and subcultured before use to ensure that all the organisms were dead.

The last group of special diet animals was used as controls.

The distribution of animals in these groups is shown in Table I.

TABLE I Diet administered and intraperitoneal challenge of five groups of albino rats

\begin{tabular}{|c|c|c|}
\hline Group no. & Diet & Intraperitoneal inoculation \\
\hline $\begin{array}{l}1 \\
2\end{array}$ & Normal & $\begin{array}{l}\text { Nil-Control } \\
10^{9} \text { gonococci }\end{array}$ \\
\hline $\begin{array}{l}3 \\
4 \\
5\end{array}$ & Special & $\begin{array}{l}10^{9} \text { gonococci } \\
10^{9} \text { dead gonococci } \\
\text { Nil-Control }\end{array}$ \\
\hline
\end{tabular}

\section{Results}

The weekly average weight of each group of rats and the average complement levels at the beginning and end of the experiment are recorded in Tables II an III. On an average each rat on the normal diet ate $12.5 \mathrm{~g}$. daily, whereas those on the special diet only ate $5.8 \mathrm{~g}$. per day. The weight loss among the latter groups in the 4-week period averaged about 25 per cent. of their original body weight. This could largely be explained by their intake of food being only half that of the groups on normal diet. 
TABLE II Changes in total body weight of albino rats maintained on various diets for a period of 4 weeks

\begin{tabular}{|c|c|c|c|c|c|c|}
\hline \multirow[t]{2}{*}{$\begin{array}{l}\text { Group } \\
\text { no. }\end{array}$} & \multirow[t]{2}{*}{ Diet } & \multirow{2}{*}{$\begin{array}{l}\text { Average } \\
\text { weight } \\
\text { before } \\
\text { experiment } \\
\text { (g.) }\end{array}$} & \multicolumn{4}{|c|}{$\begin{array}{l}\text { Total body weight } \\
\text { at end of week }(g .)\end{array}$} \\
\hline & & & 1 & 2 & 3 & 4 \\
\hline $\begin{array}{l}1 \\
2\end{array}$ & Normal & $\begin{array}{l}200 \\
200\end{array}$ & $\begin{array}{l}208 \\
207\end{array}$ & $\begin{array}{l}219 \\
218\end{array}$ & $\begin{array}{l}229 \\
228\end{array}$ & $\begin{array}{l}238 \\
237\end{array}$ \\
\hline $\begin{array}{l}3 \\
4 \\
5\end{array}$ & Special & $\begin{array}{l}195 \\
198 \\
196\end{array}$ & $\begin{array}{l}178 \\
185 \\
187\end{array}$ & $\begin{array}{l}163 \\
169 \\
164\end{array}$ & $\begin{array}{l}156 \\
152 \\
155\end{array}$ & $\begin{array}{l}149 \\
144 \\
149\end{array}$ \\
\hline
\end{tabular}

TABLE II I Complement levels in pooled rat serum at beginning and end of experiment

\begin{tabular}{|c|c|c|c|}
\hline \multirow{2}{*}{$\begin{array}{l}\text { Group } \\
\text { no. }\end{array}$} & \multirow[b]{2}{*}{ Diet } & \multicolumn{2}{|c|}{ Complement levels in pooled rat serum } \\
\hline & & $\begin{array}{l}\text { Titre before start } \\
\text { of experiment }\end{array}$ & $\begin{array}{l}\text { Titre at end of } \\
\text { 4-week period }\end{array}$ \\
\hline $\begin{array}{l}1 \\
2\end{array}$ & Normal & $\begin{array}{l}1: 8 \\
1: 8\end{array}$ & $\begin{array}{l}1: 8 \\
1: 8\end{array}$ \\
\hline $\begin{array}{l}3 \\
4 \\
5\end{array}$ & Special & $\begin{array}{l}1: 8 \\
1: 8 \\
1: 8\end{array}$ & $\begin{array}{l}1: 2 \\
1: 2 \\
1: 2\end{array}$ \\
\hline
\end{tabular}

All the rats proved resistant to experimental infection. 72 hours after inoculation with live gonococci, the rats in Group 3 were killed and samples of heart blood, spleen, and liver were examined for gonococci. No organisms were seen in stained films or isolated on culture.

The foregoing experiment was repeated with the addition of two extra groups of rats, so that the suppression of phagocytosis could be investigated. Thus, Group 6 was given a normal diet and Group 7 the special diet. At the end of the third week both groups were given a subcutaneous injection of Myeleran (15 mg./kg. suspended in olive oil). Total white cell counts were checked and 9 days after the administration of Myeleran they averaged 200/cu. $\mathrm{mm}$. (White cell counts in normal controls averaged $7,500 / \mathrm{cu}$. mm.). Subsequently, all groups were challenged as before using the same inoculum of live gonococci, and when they were tested by the same procedures as in the first experiment, there was no evidence of infection by the gonococci.

\section{Discussion}

Despite attempts to lower both the cellular and humoral defences, all rats examined were still resistant to gonococcal infection. At the end of 4 weeks on diet, serum from both test and control groups of rats was examined. No difference was detected in the lytic action of the serum on gonococci in vitro, serum from both groups of animals was rapidly bactericidal; test gonococci were killed in
2 min., as judged by viable counts using the method of Miles and Misra (1938). Electron microscope studies on the site of action were carried out and in brief they showed widening of periplasmic spaces and holes in the cytoplasmic membrane, with loss of cytoplasmic contents. Rowley (1970) has suggested that natural antibody level at the time of infection is the most important factor in determining the susceptibility of different animal hosts to infection. These findings entirely support the view that the resistance of rats to experimental infection is due to the destruction of the gonococci by certain inherent serum factors.

\section{Summary}

Feeding rats on a special diet containing DLethionine failed to reduce their natural resistance to infection by Neisseria gonorrhoeae. Even when the total white cell count of rats on this diet was greatly reduced by the action of Myeleran, the results were not altered. The dramatic bactericidal effect of the serum in vitro on both test and control rats demonstrates that the mechanism of destruction of gonococci was unaffected by this diet.

This work was supported by a grant from the Medical Research Council. I wish to thank Prof. M. G. McEntegart for his help in preparing this manuscript.

\section{References}

Bertóx, L., Kemenes, F., and Simon, G. (1964) f. Path. Bact., 88, 329

— and SZEMERÉdi, J. (1967) Ibid., 94, 194

HiLl, J. (1943) Amer. F. Syph., 27, 733

Miles, A. A., and MisRA, S. S. (1938) f. Hyg. (Lond.), 38, 732

Pillemer, L. (1956) Ann. N. Y. Acad. Sci., 66, 233

Price, I. N. O. (1943) Brit. F. vener. Dis., 25, 157

Rowley, D. (1970) In 'Developmental Aspects of Antibody Formation and Structure', ed. J. Sterzl and I. Riha, vol. 1, p. 207. Academic Press, New York.

Résistance des rats à l'infection expérimentale avec Neisseria gonorrhoeae malgré des tentatives pour modifier les défenses cellulaires et humorales

SOMMAIRE

En nourrissant des rats avec un régime spécial contenant de la DL-éthionine on ne réussit pas à réduire leur résistance naturelle à l'infection par Neisseria gonorrhoeae. Même lorsque le Myleran eut fortement réduit le nombre total des leucocytes chez les rats soumis à ce régime, les résultats furent les mêmes. L'effect bactéricide puissant du sérum in vitro, aussi bien chez les animaux traités que chez les témoins, montre que ce régime ne modifie pas le mécanisme de destruction des gonocoques. 